\title{
Interactive comment on "Biogeochemical Impact of Cable Bacteria on Coastal Black Sea Sediment" by Martijn Hermans et al.
}

\section{Anonymous Referee \#1}

Received and published: 13 August 2020

The study documents the effect of cable bacteria on sediment geochemistry in repacked sediment cores on sediment collected from the Black Sea. The findings support current paradigms in the cable bacteria literature. This is a nice case study that has been well presented and written up. The dominance of cable bacteria in the oxygen budget is an interesting finding. There is also some additional data on element mapping that sheds further light on the effect of cable bacteria on sediment geochemistry at different sites. I only have a few relatively minor comments and suggestions for improvement.

The authors used the classic sediment repacking method to start a cable growth cycle. What effect might homogenisation have had on the final findings? For example, would siderite be likely to be so close to the surface under normal circumstances. 
Line 163 - no need to say 'bottom water' just water samples? Line 172 - please elaborate a little on exactly what you mean by salt corrections Line 205 - could you add a sentence on how the embedding was achieved? Line 210 onwards - consider adding this to methods also Line 261 - Only Ca and Si fluxes are presented, I couldn't see them? Line 384 not clear what you mean here, please elaborate. Line 415 - could it be that the nitrate is just denitrified?

Also on this point, it seems that not flux measurements were made for nitrate. It seems likely that some nitrate is released to the water. It might be worth a brief discussion of a few scenarios here. All the nitrate is released to the water column, all the nitrate is denitrified by sediment bacteria and all the nitrate is denitrified by cable bacteria

Line 485 - very interesting! Line 522 - not obvious to me from from fig $8 \mathrm{~A}$, it is interesting, can you make this clearer? Line 546 I agree this is likely driven by cables, but how is this different from a straight reaction diffusion scenario (given ubiquity of cables, such a scenario does seem unlikely though). I think this idea needs a little more development and explanation as to how it might actually be applied.

Figure 3 not clear how this was generated. Based on the pictures?

Interactive comment on Biogeosciences Discuss., https://doi.org/10.5194/bg-2020-292, 2020. 